\title{
Ethical Aspects of Sustainable Development in Polish Enterprises Transporting Animals for Slaughter
}

\author{
Anna Budzik ${ }^{1}$ and Tomasz Budzik ${ }^{2}$
}

\begin{abstract}
The issue of sustainable development is currently the subject of interest of researchers from many scientific fields. The idea of sustainable development includes the economy, the society and the environment. In the context of sustainable development, the subject of animal welfare is being increasingly regarded as essential. Ensuring animal welfare is now the key issue for public opinion, livestock farmers, animal rights organizations, entrepreneurs, transport companies and slaughterhouses. Animal welfare should be applied according to Five Freedoms, which are: freedom from hunger and thirst, freedom from pain and injury, freedom from physical discomfort, freedom to express normal behavior, freedom from stress and fear. The purpose of this article is to present the current state of awareness about ensuring animal welfare as an element of sustainable development on the example of Polish companies which transport animals to slaughterhouses. As a research method the authors used the survey method. The questionnaire was addressed to the owners of enterprises transporting slaughter animals and to drivers of these enterprises. The results found out that there is a serious need to change the operation of the transport system due to ethical aspects.
\end{abstract}

Keywords: Sustainable development, animal welfare, animal transport, transport management

\section{Introduction}

The problem of sustainable development is currently an important component of the activity associated with transport. Road transport is one of transport sectors which the assumptions of sustainable development mostly apply to. Road transport can be used to carry almost all types of loads over various distances. The transport of live animals is fundamentally different from the transport of material goods and to a greater extent determines sustainable development.

The transport of live animals is a specific type of carriage due to the type of "load" which is a living organism. For animals, transport, particularly over long distances, carries the risk of injury and undoubtedly is a source of stress. Therefore, in the era of sustainable development, one can also observe an increased interest in animal welfare during transport. Despite numerous national and European legal requirements concerning the transport of animals for slaughter it is still the subject of discussions of livestock farmers, business environments, transport companies, slaughterhouses and also animal welfare organizations. Pro-animal organizations and other business environments have different opinions on animal welfare: whereas pro-animal organizations most of all care about the maintenance of animal welfare, business environments must take care of business and revenues. It is very difficult to reach an agreement when the two parties have different priorities. 


\section{The Link between Sustainability and Animal Welfare - Literature Review}

The concept of sustainable development emerged as a response to the rapid economic development of the early 20th century which resulted in irreversible effects in the natural environment (Bluszcz, 2018). This was related to numerous environmental disasters and these events and the related scientific publications (Burchard-Dziubińska, Rzeńca, Drzazga, 2014; Kaliski, Frączek, Szurlej, 2011; Dwyer, 2017; WedełDomaradzka, Domaradzki, 2014) concerning the need to protect the natural environment contributed to an increase in interest in the relationships at the interface of the economy, the society and the natural environment (Clemencon, 2016). These were the beginnings of the idea of sustainable development and making broad social circles aware that there are mutual relationships between the natural environment and the society (Burchard-Dziubińska, et al, 2014). Sustainable development has become the subject of great interest of scientists from different fields of research (Šoja, Anokić, Jelić, Maletić, 2016) and sustainability can be seen as a multidimensional sphere where environmental, social and economic pillars depend on human decisions (Huttmanová, 2017; Bluszcz, 2016). These three interrelated dimensions should be addressed via supportive policies and like the 2030 Agenda for Sustainable Development (United Nations, 2015) seek for the 21st century solutions for people, planet and prosperity (Armeanu, Vintila, Gherghina, 2018). The Polish legislation defines sustainable development as follows:

Sustainable development is the socio-economic development in which the process of integrating political, economic and social activities takes place, while maintaining the natural balance and durability of basic natural processes in order to guarantee the possibility of satisfying basic needs of individual communities or citizens of both the present and future generations (Prawo ochrony środowiska, art. 3, pt. 50).

Sustainable transport has emerged as one of the missions of sustainable development and developments in this sector can be assessed for their impact at a local level, regional level and global level and also across sectors (Öberg, Nilsson, Johansson, 2018).

Transport is one of the sectors of the economy which, on the one hand, is the basis for economic development and, on the other, significantly contributes to the degradation of the natural environment. Therefore, at present, transport companies take into account the assumptions of sustainable development in their strategies (Rucińska, 2014). According to Gurjar, Agarwal and Gupta, nowadays, sustainable transport is of great importance because of concerns about the environmental, economic and social impact of transport systems (Gurjar, Agarwal, Gupta, 2016).

Nowadays, the problems of sustainable development, care for the natural environment and animal welfare are increasingly discussed. In the world, there is the prevailing view that care for the natural environment and its surroundings allows people to live in better conditions and care for animal welfare results in meat and milk of better quality. Sustainable development is a way to implement the positively conducted policy of breeding management, environmental management and enterprise management, and all of this with a view to future generations (Górska, 2015). Animal welfare is inscribed in the idea of sustainable development and is also becoming the concern and the focus of interest of not only environmentalists and animal rights activists but also animal 
breeders.

The transport of animals for slaughter, in the context of the idea of sustainable development, is analyzed in terms of (Budzik, Wypych, 2013):

- causing additional environmental and social costs (additional $\mathrm{CO}_{2}$ emissions, increased motor traffic),

- maintaining animal welfare, which affects the quality of animal products and human health,

- the fact that the basis for the operation for the benefit of the welfare and protection of animals is the conviction that animals are the beings capable of feeling and their needs ought to be taken into account and the protection of animals in the 21 st century is the challenge to the civilization and culture and the manifestation of humanity,

- the transport of animals over long distances increases the risk of animal disease transmission.

The transport of animals for slaughter in terms of sustainable development also relates to ethical issues since animals in factory farming are just the raw material, which is modified and processed so as to obtain, at the least cost, as much product from it as possible and when it becomes useless, it is transported to the slaughterhouse (Budzik, Wypych, 2013). The transport of animals for slaughter is one of more important stages of pre-slaughter handling which, in addition to exerting significant impact on animal welfare, also consequently affects the quality of meat (Cierach, Idaszewska, 2014).

Factory farming and its vast scale of production, which causes the concentration of animals of one species, has significant impact on technical solutions used in transport. Of all transport sectors, due to directness of "delivery", this is road transport that is the main and applied on a large scale form of activity for transporting animals for slaughter. This applies to the transport of animals for slaughter over long and medium distances (Ślipek, Frączek, Francik, Cieślikowski, Pedryc, 2015; Dobrzański, Dobrzańska, Klisko, 2012). Road transport is most frequently used for the movement of animals between the place of their breeding and the slaughterhouse. The means of transport for carriage of animals for slaughter must meet certain technical requirements so as to ensure a safe and humane process of animal treatment (Cierach, Idaszewska, 2014).

In the literature, the most common indicators of animal welfare are the following (Mroczek, 2013; T. Bombik, E. Bombik, Biesiada-Drzyzga, 2013; Greggor, et al., 2018):

- physiological (temperature, heart rate, respiratory rate, electrocardiography, blood pressure, hematological, biochemical and immunological indicators),

- behavioral (no mental reaction: cannibalism, feather-pecking or walking in circles), - health (appearance of an animal, its condition, low incidence of digestive, respiratory diseases and lack of reproductive disorders),

- production (quantitative increase in production and reduction in maintenance costs),

- zootechnical (good condition of skin),

- technical and technological parameters of the livestock building (area of livestock housing, number of animals).

In order to determine animal welfare, the ethical criterion is also important, which states that animals should be treated as the beings capable of suffering and not the object in the production process. This is human sensitivity to the suffering and pain of animals that 
determines the achievement of a high level of animal welfare. From the point of view of animal breeders, the most important indicator of animal welfare should be their health, however, in practice, it occurs that breeders strive to achieve high productivity and low investment at the expense of animal welfare. The economic criteria appear to be unfavorable for animals (T. Bombik, et al., 2013).

The indicators of poor welfare, among others, are: shortened life expectancy, chronic emaciation, poor condition of skin, lameness, self-mutilation, reduced fertility, decline in the productivity of animals, physiological and behavioral problems and aggressive behavior among animals (Mroczek, 2013; Broom, 1992).

The scientists dealing with animals in terms of production in factory farming have their own view on the issue of animal welfare: "If an animal consumes food, behaves normally and gains weight, it means that its welfare is maintained" (Sowa, 2013) - says professor Zbigniew Dobrzański, the head of the department of Hygiene and Animal Welfare of Wrocław University of Environmental and Life Sciences. In response to the problem of limiting the movement of broiler chickens which, due to enormous density, cannot move in the last week before slaughter, professor Z. Dobrzański claims(Sowa, 2013):

For the first four weeks broilers can move and they do, at the end of fattening, this is pointless. They move over a limited distance to consume feed, only when the light is on. Broilers are not to move but to gain weigh (Sowa, 2013).

It is no secret that the companies dealing with factory farming are not interested in revealing the conditions in which animals are kept. They assure consumers that animals are treated while maintaining high animal welfare and advertisements showing happy animals in the meadow are just to strengthen their confidence in this view (Grabowska, 2014). The recordings from investigations conducted secretly in factory farms (2017) on animal cruelty are really convincing although basically they are not necessary to realize the suffering of these animals (Foer, Dyminska, 2013).

According to E. Albińska, minimizing the suffering of animals is an important aspect of sustainable and ethical food production. Animal mistreatment and not providing them with appropriate welfare results in consequences which directly affect the natural environment and also human health. The issue of the quality of life of animals is so important that it is inscribed in the concept of sustainable development (Albińska, 2013). Arto O. Salonen and Tula T. Helne claim that there is a strict connection between being on vegetarian diets and sustainable development and the advantages of vegetarian diets are remarkable: from human health, global heath, global food security to animal welfare (Salonen, Helne, 2012). In the meantime, the people following vegetarian diets are still not taken seriously. People do not want to remember the times when meat was consumed only once a week and it was relatively recently since 50-70 years ago. This has been enough for a daily cold cut sandwich to become obviousness (Albińska, 2013). The abundance of cold cuts and meats in shops and on people's tables is the evidence of the welfare of the country and of every family. All of this influences "dignifying" the acts the result of which is an increase in the number of animal deaths. The meat industry is doing well, operating thoroughly, scientifically and modernly and is supported by the law, economy, science, industry and religion (Smaga, 2010).

With an increasing number of people concerned about how animals are used to produce food, the interest in the welfare of farm animals is receiving also increased attention from 
the public (Mclennan, 2018; Grandin, Shivley, 2015; Frey, Pirscher, 2018). Consumers nowadays are very demanding about animal products not only when it comes to their healthfulness but also they are interested in how animals were treated on farms, in transport and slaughterhouses (Gallo, Tarumán, Larrondo, 2018). This new approach to the issue concerning animal welfare has led to the establishment of solid requirements to prevent unnecessary pain to farm animals regardless of where they are.

Every day millions of farm animals are transported all over the world and the road transport of farm animals is an essential part of the widespread farm production system (Padalino, Tullio, Cannone, Bozzo, 2018). The traceability of animals within the European Union is an important and fundamental issue in securing consumer confidence and in prevention in case of spreading animal diseases (Di Pasquale, et al. 2009).

The TRACES system is an IT system for notification, issuing certificates and monitoring the import, transit, exports and trade within the EU of live animals and animal products. It was created on the basis of the decision of the Commission (WE) No. 2004/292 on the introduction of the TRACES system and amending Decision 92/486/EWG (2004/292/EC). It has been applied by the veterinary authorities of all the EU Member States since 1 January 2005. This system is to facilitate trade and increase the safety of the food chain in terms of animals and animal products. It allows the veterinary authorities to transmit information which provides an opportunity to identify and trace the movement of live animals and animal products. The users of the TRACES system are competent authorities and economic entities of the EU Member States, third countries and the EFTA countries (European Commission, 2018; Padalino, Tullio, Cannone, Bozzo, 2018). Table 1 shows the data from the TRACES REPORT on selected animals species that were transported for slaughter between 2014 and 2016 among the Member States of the European Union. The report also includes other purposes for transported animals, like production, breeding and fattening not included in Table 1. The number of cattle transported for slaughter between 2014 and 2016 increased by $6 \%$. In the same period of time the number of pigs for slaughter decreased by $11 \%$, the number of horses decreased by $15 \%$ and the number of sheep for slaughter decreased by $10 \%$. The reasons for these results were not analyzed in the report (European Commission, a,b,c).

Table 1. The number of live animals transported for slaughter (intra Union trade and import to/export from the EU per species

\begin{tabular}{|l|c|c|c|c|}
\hline & $\mathbf{2 0 1 4}$ & $\mathbf{2 0 1 5}$ & $\mathbf{2 0 1 6}$ & \% change 2014-2016 \\
\hline Cattle for slaughter & 601,345 & 622,689 & 635,255 & $+6 \%$ \\
\hline Pigs for slaughter & $11,172,268$ & $10,527,502$ & $9,944,268$ & $-11 \%$ \\
\hline Horses for slaughter & 30,938 & 28,754 & 26,19 & $-15 \%$ \\
\hline Sheep for slaughter & $2,084,457$ & $2,348,468$ & $2,286,867$ & $-10 \%$ \\
\hline
\end{tabular}

Source: Own study based on "The Report from the TRACES system"

Farm animal transport brings about a serious stress to them: they are forced to move (sometimes using painful stimulations), changes in the structure of animal groups causes emotional and physical stress and other environmental circumstances, e.g. noise, smell, 
changes in temperature, humidity, vibrations and lack of food and water (Dousek, Večerek, Valcl, Chloupek, Pištěková, 2002; Llonch, et al., 2018). The main factors that affect farm animal welfare during transport include the pre-, during- and post- road transport (Marahrens, et al. 2011; Šímová, Večerek, Passantino, Voslářová, 2016; Laaksonen, Jokelainen, Pusenius, Oksanen, 2017; Broom, 2005). Pre-journey factors are as follows (Padalino, et.al., 2018):

- on farm handling,

- rearing conditions,

- assembly of animals,

- classifying,

- weighing,

- assimilation into a new environment;

- regrouping

- mixing with unfamiliar animals,

- fitness for transport,

- handling at loading.

Factors during the journey are as follows (Padalino, et.al., 2018):

- duration of the journey

- withdrawal of feed and water,

- thermal and physical conditions inside the vehicle,

- overcrowding,

- absence of partitions

- driving skills,

- noise vibrations,

- road quality.

Post-journey risk factors that have impact on animal welfare are as follows (Padalino, et.al., 2018):

- handling at unloading,

- duration of rest period,

- recovery practices,

- regrouping,

- and mixing with unfamiliar animals.

The first principles concerning animal welfare were examined by Professor Brambell in the United Kingdom in 1965. The committee led by Brambell was assigned by the UK government to explore the welfare of animals that were kept in intensive livestock husbandry systems (Harris, 2005). In the report of the Brambell Committee, animal welfare was defined:

Welfare is a wide term that embraces both the physical and mental well-being of the animal. Any attempt to evaluate therefore must take into account the feelings of animals that can be derived from their structures and function and also from their behavior (Brambell, 1965).

The report also formulated Five Freedoms of Animals that should be fulfilled in order to 
provide animal welfare (Brambell, 1965). The welfare of animals kept in the farm, in transport or in the slaughterhouse should be assessed using Five Freedoms. Five Freedoms determine the state the conditions of animal welfare included in the Brambell Report in 1965 and subsequently developed by Farm Animals Welfare Council's Freedoms should be adjusted to (El-Jai, 2008).

Five Freedoms are (Farm Animal Welfare Committee, 2016):

1. freedom from hunger or thirst - animals must be provided with access to fresh water and feed,

2. freedom from discomfort - animals must be provided with an appropriate environment (including shelter and resting area),

3. freedom from pain, injury or disease - animals must be provided with appropriate veterinary care and treatment if necessary,

4. freedom to express normal behavior - animals must be provided with sufficient space, proper facilities and company of animals of their own species,

5. freedom from fear and distress - animals must be provided with appropriate treatment and care not causing mental suffering of animals.

Farm animals experience three stages in their lives, which are: production, transport and slaughter. Animal welfare should be applied according to Five Freedoms at each of these stages (Harris, 2005). Other requirements regarding the conditions of breeding or equipping the vehicle transporting animals, loading and unloading equipment, according to the law should be adopted to the specific species and the age of animals. It is therefore considered that animal welfare should be ensured according to the same general guidelines for all animal species.

\section{Methodology}

The hypothesis of the paper is the statement that ethical aspects of sustainable development determine the change in the operation of the system of transporting animals for slaughter in enterprises.

The survey method was used for the purposes of the research. The addressees of the questionnaire were the owners of enterprises transporting animals for slaughter and drivers in these enterprises in the area of the Silesian Voivodeship. The database of the companies authorized to transport animals for slaughter was created on the basis of the information contained on the website of the Chief Veterinary Inspectorate. The database was dated as of September 2017. In this database, in the Silesian Voivodeship, there were registered 360 entities licensed to transport animals. After excluding the companies dealing with the transport of animals not included in the problem area of the present study (such as: animal shelters, veterinary clinics, transport of pets, transport of pigeons, transport of fish or transport of wild and exotic animals), 120 enterprises were selected for further analyses. The outcome was 94 questionnaires completed by the enterprise owners and 92 filled in by the drivers transporting animals.

\section{The Research Results}

The survey allowed for obtaining the information on ensuring animal welfare in 
the surveyed enterprises. In this case, the respondents could select more than one response. The results are presented in Table 2.

Table 2. What does ensuring animal welfare in the surveyed enterprise consists in according to the owners?

\begin{tabular}{|l|c|c|}
\hline $\begin{array}{l}\text { Ensuring animal welfare in your company } \\
\text { consists in: }\end{array}$ & $\begin{array}{c}\text { Number of } \\
\text { indications }\end{array}$ & $\begin{array}{c}\text { Percentage of } \\
\text { indications }\end{array}$ \\
\hline Mainly in satisfying emotional needs & 29 & $30.9 \%$ \\
\hline Mainly in satisfying biological needs & 50 & $53.2 \%$ \\
\hline Mainly in providing natural breeding conditions & 25 & $26.6 \%$ \\
\hline It is difficult to say & 5 & $5.3 \%$ \\
\hline A total of responses & 109 & $100 \%$ \\
\hline
\end{tabular}

Source: Own study based on the results of the survey

According to $53.2 \%$ of the owners of enterprises transporting animals, their welfare consists mostly in satisfying their biological needs, 30.9\% claim that ensuring animal welfare is also related to the need to meet their emotional needs, $26.6 \%$ express an opinion that animal welfare consists in providing natural breeding conditions. Only $5.3 \%$ of the owners selected the answer that it is difficult to say what ensuring animal welfare consists in.

Thinking in terms of sustainable development, including animal welfare is an important issue in the decision-making process of enterprises transporting animals and in management since animal welfare must be considered at each stage of transport organization. Although the issue of animal welfare in transport is regulated by the EU provisions as well as the national ones, the concept of welfare is not easy to specify and more and more frequently it occurs in the context of sustainable development. Most definitions of animal welfare refer to satisfying both biological and emotional needs of animals. Animal welfare can be related to both environmental, economic and social governance. Maintaining good health of animals is associated with lower veterinary costs and larger productive capacity. Moreover, appropriate treatment of animals meets the requirements of the environmental protection, not only in terms of production of uncontaminated food but also technological and organizational solutions concerning e.g. the transport of animals. Social governance is realized in this regard mainly in the context of cultural conditions in relation to animal treatment.

The requirements necessary to maintain welfare were included in five animal rights. These rights assume that animals should be free from hunger and thirst, discomfort, pain and diseases, fear and distress and free to express normal behavior (Unesco, 1978). According to the majority of the owners, ensuring animal welfare mostly consists in satisfying biological needs of animals. While referring to the responses concerning welfare, it can be concluded that most owners do not meet the requirements in terms of animal welfare or the responses result from their ignorance in this field.

The survey also allowed for determining whether there was a need to improve the conditions of animal transport in the analyzed enterprises, as shown in Table 3. 
Table 3. The need to improve the conditions of animal transport in the enterprises

\begin{tabular}{|l|c|c|}
\hline $\begin{array}{l}\text { In your opinion, is there a need to improve the } \\
\text { conditions of animal transport in your company? }\end{array}$ & $\begin{array}{c}\text { Number of } \\
\text { enterprise }\end{array}$ & $\begin{array}{c}\text { Percentage of } \\
\text { enterprises }\end{array}$ \\
\hline Definitely not & 25 & $26.6 \%$ \\
\hline Rather not & 31 & $33 \%$ \\
\hline I have no opinion & 21 & $22.3 \%$ \\
\hline Rather yes & 16 & $17 \%$ \\
\hline Definitely yes & 1 & $1.1 \%$ \\
\hline Total & 94 & $100 \%$ \\
\hline
\end{tabular}

Source: Own study based on the results of the survey

The data presented in Table 3 indicate that $33 \%$ of the respondents rather do not see any need to improve the conditions of animal transport in their companies, $26.6 \%$ definitely see no need, $22.3 \%$ have no opinion on this issue. In turn, $17 \%$ of those questioned rather see the need to improve the conditions of animal transport and $1.1 \%$ definitely can see such a need. Therefore, it can be concluded that the fact that there is no need to improve the conditions of animal transport and no opinion on this issue, which amounts to $81.9 \%$ of all the responses, can indicate no direct contact of the owners and managers of enterprises with transport and animals and ignorance in this field. Table 4 contains the information determining how the surveyed enterprises perceive the impact of consumer awareness on increasing animal welfare during transport.

Table 4. The impact of consumer awareness on increasing animal welfare during transport

\begin{tabular}{|l|c|c|}
\hline $\begin{array}{l}\text { In your opinion, what is the impact of consumer } \\
\text { awareness on increasing animal welfare? }\end{array}$ & $\begin{array}{c}\text { Number of } \\
\text { enterprises }\end{array}$ & $\begin{array}{c}\text { Percentage of } \\
\text { enterprises }\end{array}$ \\
\hline Definitely large & 7 & $7.4 \%$ \\
\hline Rather large & 10 & $10.6 \%$ \\
\hline Medium & 23 & $24.5 \%$ \\
\hline Rather small & 29 & $30.9 \%$ \\
\hline Definitely small & 25 & $26.6 \%$ \\
\hline Total & 94 & $100 \%$ \\
\hline
\end{tabular}

Source: Own study based on the results of the survey

$30.9 \%$ of the respondents believe that consumer awareness has a rather small impact on increasing animal welfare and $26.6 \%$ claim that the impact is definitely small. $24.5 \%$ of those questioned state that the impact of consumer awareness on increasing animal welfare is medium, $10.6 \%$ respond that it is large whereas $7.4 \%$ claim that the impact is definitely large. This means that $57.5 \%$ of the owners of enterprises underestimate the growing interest of the public and animal protection organizations in maintaining animal welfare during their breeding or transport or they have no knowledge in this field.

The drivers employed in the companies transporting animals for slaughter were requested to answer the question in what way the conditions of animal welfare during transport are met in the companies they work for. More than one response could be selected. 
Table 5. The way of ensuring animal welfare during transport

\begin{tabular}{|l|c|c|}
\hline $\begin{array}{l}\text { In what way the conditions of animal welfare during transport are } \\
\text { met in your company? (more than one answer can be selected) }\end{array}$ & $\begin{array}{c}\text { Number } \\
\text { of drivers }\end{array}$ & $\begin{array}{c}\text { Percentage } \\
\text { of drivers }\end{array}$ \\
\hline Through access to food/water & 39 & $42.4 \%$ \\
\hline Through eliminating stress factors & 14 & $15.2 \%$ \\
\hline Through the company of animals of the same species & 18 & $19.6 \%$ \\
\hline Through access to veterinary care & 18 & $19.6 \%$ \\
\hline Through the resting area/shelter & 9 & $9.8 \%$ \\
\hline Through the living space & 7 & $7.6 \%$ \\
\hline Others & 1 & $1.1 \%$ \\
\hline Total & 92 & $100 \%$ \\
\hline
\end{tabular}

Source: Own study based on the results of the survey

$42.4 \%$ of the surveyed drivers claim that animal welfare during transport is provided through access to food or water, $15.2 \%$ of those questioned claim that animal welfare is ensured through elimination of stress factors, $19.6 \%$ respond that animal welfare is provided by the company of animals of the same species, $19.6 \%$ answer that it is ensured through access to veterinary care, $9.8 \%$ of the surveyed drivers believe that it is provided through the resting space or shelter, $7.6 \%$ that it is through providing the living space. $1.1 \%$ claim that animal welfare during transport is ensured through organized training. Although there was a possibility of selecting more than one response, none of the drivers did so. This means that the drivers, like the owners of the enterprises transporting animals for slaughter, do not have full knowledge of animal welfare and may not fully understand its significance. Table 6 includes the data concerning the operations of other employees or enterprises resulting in deterioration in animal welfare.

Table 6. The occurrence of the operations of other employees or enterprises resulting in deterioration in animal welfare.

\begin{tabular}{|l|c|c|}
\hline $\begin{array}{l}\text { As a person responsible for animal transport, have you come } \\
\text { across the actions of other employees and enterprises } \\
\text { resulting in deterioration in animal welfare? }\end{array}$ & $\begin{array}{c}\text { Number } \\
\text { of drivers }\end{array}$ & $\begin{array}{c}\text { Percentage } \\
\text { of drivers }\end{array}$ \\
\hline Yes & 5 & $5.4 \%$ \\
\hline No & 87 & $94.6 \%$ \\
\hline Total & 92 & $100 \%$ \\
\hline
\end{tabular}

Source: Own study based on the results of the survey

It can be noted that the vast majority, since as much as $94.6 \%$, of the surveyed drivers claim that they have not come across the operations of other employees or enterprises resulting in deterioration in animal welfare. Only 5.4\% of the drivers claim that they have come across the actions having impact on a decline in animal welfare of other workers or enterprises. These results clearly indicate that, subject to certain exceptions, animals are treated well by the staff of the enterprises transporting animals. However, on the other hand, as established in the previous question of the survey, the drivers lack extensive and full knowledge of animal welfare.

Table 7 presents the data concerning the types of actions of other drivers or enterprises resulting in deterioration in animal welfare which the surveyed drivers have come across. 
Table 7. Types of actions of other drivers or enterprises resulting in deterioration in animal welfare

\begin{tabular}{|l|c|}
\hline $\begin{array}{l}\text { What types of actions, if any, of other employees and enterprises } \\
\text { resulting in deterioration in animal welfare have you come across? }\end{array}$ & $\begin{array}{c}\text { Number } \\
\text { of drivers }\end{array}$ \\
\hline No access to water and feed & 2 \\
\hline No rest during long transport & 0 \\
\hline Animals were transported in excessive density & 2 \\
\hline Means of transport were in a very poor technical and sanitary condition & 1 \\
\hline Cruelty to animals during loading and unloading & 0 \\
\hline Others & 0 \\
\hline Total & 5 \\
\hline
\end{tabular}

Source: Own study based on the results of the survey

The data presented in Table 7 indicate that of 5 surveyed drivers who have come across the behavior of other drivers or enterprises resulting in deterioration in animal welfare during transport, 2 indicate that it was no access to feed and water, 2 that animals were transported in excessive density and 1 points out that the means transporting animals were in a very poor technical and sanitary condition. None of the surveyed drivers claims that deterioration in the welfare of the transported animals was caused by the lack of rest during long transport or cruelty to animals during loading and unloading.

In order to verify the hypothesis formulated in the paper, which is: ethical aspects determine the change in the operation of the system of the transport of animals for slaughter in enterprises, there were also analyzed the relationships between the variables:

1. Consumer awareness and the assessment of animal welfare (Table 8).

2. The need to improve the conditions of animal transport and the operations of drivers or employees of enterprises resulting in deterioration in animal welfare ( Table 9).

3. The need to improve the conditions of animal transport and the number of actions taken in order to provide the conditions of welfare (Table 10).

4. The need to improve the conditions of animal transport and the assessment of the level of animal welfare (Table 11).

Table 8. The Chi-square test: consumer awareness and the assessment of animal welfare

\begin{tabular}{|l|c|c|c|}
\hline The relationship between the variables & $\begin{array}{c}\text { Value of the } \\
\text { Chi-square test }\end{array}$ & $\begin{array}{c}\text { Degrees of } \\
\text { freedom }\end{array}$ & p-value \\
\hline $\begin{array}{l}\text { Consumer awareness } \\
\text { and } \\
\text { the assessment of animal welfare }\end{array}$ & 155.533 & 93 & 0,000 \\
\hline
\end{tabular}

$\mathrm{P}=0.05$

Source: Own study based on the results of the survey

On the basis of the Chi-square test presented in Table 8, it can be concluded that there are statistically significant relationships between the variables $(p=0.000)$. Therefore, it can be concluded that consumer awareness translates into the assessment of animal welfare. 
Table 9. The Chi-square test: the need to improve the conditions of animal transport in the company and the occurrence of actions of other drivers or employees of enterprises resulting in deterioration in animal welfare.

\begin{tabular}{|l|c|c|c|}
\hline The relationship between the variables & $\begin{array}{c}\text { Value of the } \\
\text { Chi-square } \\
\text { test }\end{array}$ & $\begin{array}{c}\text { Degrees of } \\
\text { freedom }\end{array}$ & p-value \\
\hline $\begin{array}{l}\text { The need to improve the conditions of animal } \\
\text { transport in the company } \\
\text { and } \\
\text { the occurrence of actions of other drivers or } \\
\text { employees of enterprises resulting in } \\
\text { deterioration in animal welfare }\end{array}$ & 9.500 & 91 & 1.000 \\
\hline
\end{tabular}

$\mathrm{P}=0.05$

Source: Own study based on the results of the survey

The test results presented in Table 9 do not indicate the statistically significant relationship between the variables $(p=1.000)$. This means that there is no relationship between the need to improve the conditions of animal transport in the company and the occurrence of actions of other drivers or employees of enterprises resulting in deterioration in animal welfare.

Table 10. The Chi-square test: the need to improve the conditions of animal transport in the company and the number of actions taken to provide welfare

\begin{tabular}{|l|c|c|c|}
\hline The relationship between the variables & $\begin{array}{c}\text { Value of the Chi- } \\
\text { square test }\end{array}$ & $\begin{array}{c}\text { Degrees of } \\
\text { freedom }\end{array}$ & p-value \\
\hline $\begin{array}{l}\text { The need to improve the conditions of animal } \\
\text { transport in the company } \\
\begin{array}{l}\text { and } \\
\text { the number of actions taken to provide the } \\
\text { conditions of welfare }\end{array}\end{array}$ & 106.000 & 91 & 0.134 \\
\hline
\end{tabular}

$\mathrm{P}=0.05$

Source: Own study based on the results of the survey

The test results presented in Table 10 indicated that there was not statistically significant relationship between the variables $(p=0.134)$. This implies that there is no relationship between the need to improve the conditions of animal transport in the company and the number of action taken to provide the conditions of welfare.

Table 11. The Chi-square test: the need to improve the conditions of animal transport in the company and the assessment of animal welfare in the company

\begin{tabular}{|l|c|c|c|}
\hline The relationship between the variables & $\begin{array}{c}\text { Value of the } \\
\text { Chi-square test }\end{array}$ & $\begin{array}{c}\text { Degrees of } \\
\text { freedom }\end{array}$ & p-value \\
\hline $\begin{array}{l}\text { The need to improve the conditions of animal } \\
\text { transport in the company } \\
\text { and } \\
\text { the assessment of animal welfare in the company }\end{array}$ & 108.333 & 91 & 0.103 \\
\hline
\end{tabular}

$\mathrm{P}=0.05$

Source: Own study based on the results of the survey 
The results of the Chi-square tests presented in Table 11 indicate that there is no statistically significant relationship between the variables $(p=0.103)$. Therefore, it can be concluded that the need to improve the conditions of animal transport in the company does not affect the assessment of animal welfare.

\section{Conclusions}

Ethical aspects in the transport of animals for slaughter were related to the need of the respondents in the field of respecting animal rights and their welfare. The analysis of the relationships allows for the conclusion that basically only consumer awareness affects the assessment of animal welfare in the enterprises transporting animals for slaughter. This indicates the need to change the operation of the transport system due to ethical aspects. The awareness of the needs and feelings of animals must also occur among the owners and drivers of the enterprises dealing with animal transport. Therefore, the hypothesis was verified positively.

Through appropriate transport management one can affect the aspects of sustainable development and animal welfare. The project by the European Commission - DG SANTE is to improve animal welfare during transport. Under the project, there were developed and widespread the Manuals of Good Practices in the field of management of the transport of animals for slaughter, fattening or breeding. The project began in 2015 and finished at the end of 2018 (Animal Transport Guides and Best Practice in Europe). The project contained a number of documents on handling different animal species prior to transport, during transport and unloading. In one of the documents one may find the guidelines on the most important solutions within the framework of management of the transport of animals for slaughter. They are divided into three parts (Lista kontrolna dla kierowcy: Czy jesteś gotowy? 2017):

1) Preparations for transport. It is necessary:

- to check the condition of the vehicle before setting up: its cleanliness, ventilation, partitions, locks, floors (bedding), loading/unloading equipment and vehicle labelling,

- to take documents necessary on the route: carrier and guard license, permit, certificate of approval of the means of transport, a contingency plan, animal identification documents,

- to ensure whether animals have feed and water. It is also necessary to check whether the watering system is working.

- to take the journey log to transport animals abroad. It is also necessary to control the system monitoring the route and temperature.

2) Loading/unloading. It is necessary:

- to check on the animals and load exclusively the ones which are capable of being transported,

- to park the vehicle close to the place of loading/unloading so as to avoid extreme weather conditions,

- stay safe on the spot and check the cleanliness of the loading/unloading area,

- to sanitize and check the proper preparation and arrangement of equipment for loading/unloading so as to avoid the injury of animals, 
- to check partitions and ventilation during loading.

- During the journey it is necessary:

- to check if all the doors are locked during transport,

- to drive carefully to prevent the suffering and injury of animals,

- to avoid traffic jams and delays during transport,

- to conduct the general inspection of the vehicle and animals after each stop. It is necessary to isolate and treat (if necessary and possible) sick or injured animals.

- to consider appropriate conditions of treatment of different animal species,

- to ensure appropriate and sufficient feeding/watering during each stop.

Additionally, the document includes the frequency of feeding and watering of different animal species, the maximum travelling time and temperatures at which the transport of animals should be avoided.

\section{References}

2004/292/EC: Commission Decision of 30 March 2004 on the introduction of the Traces system and amending Decision 92/486/EEC (Text with EEA relevance) (notified under document number $\mathrm{C}(2004)$ 1282)

5 najgłośniejszych śledztw Otwartych Klatek. (2017, June 29). Retrieved July 19, 2017, from https://www.otwarteklatki.pl/5-najglosniejszych-sledztw-otwartych-klatek/

Albińska, E. (2013, August 12). Przemysłowy chów zwierząt ma znaczący wpływ na klimat. Retrieved November 11, 2017, from http://www.chronmyklimat.pl/wideo/zielonagospodarka/przemyslowy-chow-zwierzat-ma-znaczacy-wplyw-na-klimat

Animal Transport Guides and Best Practice in Europe. (n.d.). Retrieved March 29, 2018, from http://animaltransportguides.eu/pl/o-projekcie.

Armeanu, D., Vintila, G., Gherghina, S. (2018). Empirical Study towards the Drivers of Sustainable Economic Growth in EU-28 Countries. Sustainability, 10(2), p. 4. doi:10.3390/su10010004

Bluszcz, A. (2016). Erratum to: Classification of the European Union member states according to the relative level of sustainable development. Quality \& Quantity, 50(6), p. 2592. doi:10.1007/s11135015-0285-y.

Bluszcz, A. (2018). Conditions for Maintaining the Sustainable Development Level of EU Member States. Social Indicators Research, 139(2), p. 679 doi:10.1007/s11205-017-1746-6.

Bombik, T., Bombik, E., Biesiada-Drzyzga, B. (2013). Dobrostan zwierząt w aspekcie kryteriów i metod oceny. Przegląd Hodowlany, 81(6), p. 26.

Brambell, F. W. (1965). Report of the Technical Committee to equire into the welfare of animals kept under intensive livestock husbandry systems. London: H.M.S.O.

Broom, D. (2005). Secuelas del transporte terrestre en el bienestar de los animales. Revue Scientifique Et Technique De LOIE, 24(2), 683-691. doi:10.20506/rst.24.2.1605.

Broom, D. M. (1992). Animal welfare: its scientific measurement and current relevance to animal husbandry in Europe. In Farm Animals and the Environment (pp. 252). CAB International, Wallingford.

Budzik, A., Wypych, I. (2013). Transport zwierząt rzeźnych a zrównoważony rozwój. Logistyka., p. 538.

Burchard-Dziubińska, M., Rzeńca, A., Drzazga, D. (2014). Zrównoważony rozwój-naturalny wybór, Wydawnictwo Uniwersytetu Lódzkiego, Łódź, p. 10.

Cierach, M., Idaszewska, N. (2014). Transport samochodowy zwierząt rzeźnych. Inżynieria Przetwórstwa Spożywczego, 1(4), 9, p. 21.

Clemencon, R. (2016). Sustainable Development, Climate Politics and EU-Leadership: A Historical Comparative Analysis, European Journal of Sustainable development, 5(1), p.125 Doi: 10.14207/ejsd.2016.v5n1p125.

Di Pasquale, et al. (2009). Animal welfare monitoring and livestock traceability during transport. Veterinaria italiana, 45(4), 577. 
Dobrzański, P. Dobrzańska, M. Klisko, M. (2012). Problematyka prawna transportu zwierząt, Logistyka, No. 4, 891-896.

Dousek, J., Večerek, V., Valcl, O., Chloupek, P., Pištěková, V. (2002). Protection of Animals against Cruelty: Transport of Cattle, Sheep, Goats and Pigs. Acta Veterinaria Brno, 71(4), 555. doi:10.2754/avb200271040555.

Dwyer, J. (2017, March 01). Remembering a City Where the Smog Could Kill. Retrieved April 20, 2017, from https://www.nytimes.com/2017/02/28/nyregion/new-york-city-smog.html.

El-Jai, J. (2008), Dobrostan zwierząt w naukach humanistycznych i przyrodniczych, Studia Ecologiae et Bioethicae, 6, p. 187.

European Commission. (2018, October 11). TRACES: Trade Control and Expert System. Retrieved January 14, 2019, from https://ec.europa.eu/food/animals/traces_en.

European Commission. (n.d. a). TRACES Data - Animals traded between Member States in 2016. Retrieved from https://ec.europa.eu/food/sites/food/files/animals/docs/ahsc_report_2016_en.pdf

European Commission. (n.d. b). TRACES Data - Animals traded between Member States in 2015. Retrieved from https://ec.europa.eu/food/sites/food/files/animals/docs/ahsc_report_2015_en.pdf

European Commission. (n.d. c). TRACES Data - Animals traded between Member States in 2014. Retrieved from https://ec.europa.eu/food/sites/food/files/animals/docs/ahsc_report_2014_en.pdf

Farm Animal Welfare Committee (2016), Sustainable Agriculture and Farm Animals Welfare, UK, p. 5.

Foer, J. S., Dymińska, D. (2013). Zjadanie zwierzat. Warszawa: Wydawnictwo Krytyki Politycznej, p. 287.

Frey, U. J., Pirscher, F. (2018). Willingness to pay and moral stance: The case of farm animal welfare in Germany. Plos One, 13(8). doi:10.1371/journal.pone.0202193.

Gallo, C., Tarumán, J., Larrondo, C. (2018). Main Factors Affecting Animal Welfare and Meat Quality in Lambs for Slaughter in Chile. Animals, 8(10), p. 165. doi:10.3390/ani8100165.

Górska, J. (2015). Forum Mleczarskie: Dobrostan zwierząt: Szczęśliwe krowy dają lepsze mleko? Retrieved January 20, 2019, from https://www.forummleczarskie.pl/RAPORTY/462/dobrostan-zwierzatszczesliwe-krowy/

Grabowska, B. (2014). Zmiany relacji człowiek-zwierzę, czyli cena postępu. Kultura i Wartości, (10), 116.

Grandin, T., Shivley, C. (2015). How Farm Animals React and Perceive Stressful Situations Such As Handling, Restraint, and Transport. Animals, 5(4), 1234, doi:10.3390/ani5040409.

Greggor, A., et al. (2018). Animal Welfare in Conservation Breeding: Applications and Challenges. Frontiers in veterinary science, 5, 323. doi: 10.3389/fvets.2018.00323.

Gurjar, M. J., Agarwal, A. K., Gupta, V. (2016). Applications of innovative technologies for development of sustainable transport system. Journal of Advanced Research in Automotive Technology and Transportation System, 1(1), 43.

Harris, T. (2005). Tansporte y bienestar de los animales, un tema de dimensión mundial. Revue Scientifique Et Technique De LOIE, 24(2), 647. doi:10.20506/rst.24.2.1598

Huttmanová, E. (2017). The Possibilities Of Sustainable Development Evaluation In The European Union Area. European Journal of Sustainable Development, 6(3), p. 75 doi:10.14207/ejsd.2017.v6n3p75.

Kaliski, M., Frączek, P., Szurlej, A. (2011). Brytyjskie doświadczenia a zmiana struktury źródeł energii w Polsce, Polityka Energetyczna, 14(2), pp. 144-145.

Laaksonen, S., Jokelainen, P., Pusenius, J., Oksanen, A. (2017). Is transport distance correlated with animal welfare and carcass quality of reindeer (Rangifer tarandus tarandus)? Acta Veterinaria Scandinavica, 59(1). doi:10.1186/s13028-017-0286-z;

Lista kontrolna dla kierowcy: Czy jesteś gotowy? (2017, March). Retrieved March 29, 2018, from http://animaltransportguides.eu/wp-content/uploads/2017/03/Driver-Checklist-PL-rev..pdf.

Llonch, P., et al. (2018). Chicken or the Egg: The Reciprocal Association Between Feeding Behavior and Animal Welfare and Their Impact on Productivity in Dairy Cows. Frontiers in Veterinary Science, 5. doi:10.3389/fvets.2018.00305.

Marahrens, M., et al. (2011). Risk assessment in animal welfare - Especially referring to animal transport. Preventive Veterinary Medicine, 102(2), 157-163. doi:10.1016/j.prevetmed.2011.04.010.

Mclennan, K. (2018). Why Pain Is Still a Welfare Issue for Farm Animals, and How Facial Expression Could Be the Answer. Agriculture, 8(8), p. 127. doi:10.3390/agriculture8080127

Mroczek, J. R. (2013). Dobrostan zwierząt jako element retardacji przekształcania zasobów w produkcji zwierzęcej. Inżynieria ekologiczna, 34, p. 185. 
Öberg, M., Nilsson, K. L., Johansson, C. M. (2018). Complementary governance for sustainable development in transport: The European TEN-T Core network corridors. Case Studies on Transport Policy, 6(4), p. 676. doi:10.1016/j.cstp.2018.08.006.

Padalino, B., Tullio, D., Cannone, S., Bozzo, G. (2018). Road Transport of Farm Animals: Mortality, Morbidity, Species and Country of Origin at a Southern Italian Control Post. Animals, 8(9), 155. doi:10.3390/ani8090155.

Rucińska, D. (2014). Promocja zrównoważonego rozwoju transportu-wybrane przykłady dobrych praktyk, Logistyka, 2, p. 285.

Salonen, A. O., Helne, T. T. (2012). Vegetarian Diets: A Way towards a Sustainable Society. Journal of Sustainable Development, 5(6), p.10, doi:10.5539/jsd.v5n6p10.

Šímová, V., Večerek, V., Passantino, A., Voslářová, E. (2016). Pre-transport factors affecting the welfare of cattle during road transport for slaughter - a review. Acta Veterinaria Brno, 85(3), 303-318. doi:10.2754/avb201685030303.

Ślipek, Z., Frączek, J., Francik, S., Cieślikowski, B., Pedryc, N. (2015). Wymagania projektowe dla pojazdów przeznaczonych do transportu zwierząt. Logistyka, 4, 6124-6130.

Smaga, Ł. (2010). Ochrona humanitarna zwierzat. Białystok: Agencja Wydawniczo-Edytorska EkoPress, p. 229.

Šoja, S. J., Anokić, A., Jelić, D. B., Maletić, R. (2016). Ranking EU Countries According to Their Level of Success in Achieving the Objectives of the Sustainable Development Strategy. Sustainability, 8(4), p. 306. doi:10.3390/su8040306.

Sowa, A. (2013, October 31). Kotlet z taśmy. Retrieved July 11, 2017, from https://www.polityka.pl/tygodnikpolityka/spoleczenstwo/1560297,1,tasmowe-maltretowaniezwierzat.read.

Unesco, (1978), The World Declaration of Animal Rights adopted by UNESCO on 15.10 .1978 in Paris.

United Nations, (2015). Transforming our World: The 2030 Agenda for Sustainable Development, United Nations: New York.

Ustawa z 27.04.2001 Prawo ochrony środowiska. Dz. U. 2018, poz. 799, z późn. zm.

Wedeł-Domaradzka, A., Domaradzki, A. (2014). Prawno-logistyczne aspekty powstania i funkcjonowania europejskiego systemu bezpieczeństwa na morzu. Logistyka, 6, p. 12629. 